\title{
REVIEW
}

\section{An ecosystem approach to global assessment and management of coastal waters}

\author{
K. Sherman ${ }^{1, *}$, A. M. Duda ${ }^{2}$ \\ 'United States Department of Commerce, National Oceanic and Atmospheric Administration, National Marine Fisheries \\ Service, Northeast Fisheries Science Center, 28 Tarzwell Drive, Narranganseft, Rhode Island 02882-1199, USA \\ ${ }^{2} 1818$ H Street NW, Room G-6015 Global Environment Facility Secretariat, Washington, DC 20433, USA
}

\begin{abstract}
Since the Rio Summit in 1992 the public has become increasingly aware that coastal ecosystems are under significant threat from pollution, overexploitation, and habitat loss. However, little progress has been made in sustained global actions to reverse their degraded state. It has been no small feat for the world community to come to agreement on international instruments identifying environmental and resource problems, but it is another matter altogether to muster the scientific community and the political will to enact necessary policy reforms and devote necessary funding to restore and protect valuable marine ecosystems. An ecosystems approach is emerging for the assessment and management of coastal waters around the globe utilizing modular strategies for linking science-based assessments of the changing states of large marine ecosystems to socioeconomic benefits expected from achieving long-term sustainability of their resources. To assist developing countries in implementing the ecosystems approach to marine resources development and sustainability in international waters, the Global Environment Facility and its $\$ 2$ billion trust fund has been opened to universal participation that builds on partnerships with the United Nations Development Programme, the United Nations Environmental Programme, and the World Bank
\end{abstract}

KEY WORDS: Global assessment - Large marine ecosystems · Management · Sustainability

\section{COASTAL ECOSYSTEMS IN DECLINE}

There is growing evidence of continuing degradation to coastal waters around the globe from habitat alteration, eutrophication, toxic pollution, aerosol contaminants, emerging diseases, and excessive fishing effort (FAO 1995, Epstein 1996, Duda \& Cruz 1998, Hedin 1998, Stockholm Water Symposium EMECS 1998). This evidence has led to recognition that coastal ecosystems are being adversely impacted by multiple driving forces and has accelerated efforts by scientists and resource stewards to assess, monitor, and manage coastal resources from an ecosystem perspective (Boesch 1998). However, no single international insti-

\footnotetext{
·E-mail: kenneth.sherman@noaa.gov
}

tution has been empowered to monitor the changing ecological states of marine ecosystems on a global scale and to reconcile the needs of individual nations with those of the community of coastal nations in taking appropriate mitigation and management actions.

The need for an approach to implement the assessment and management of coastal ecosystems in support of resource development and sustainability at appropriate geographic scales around the globe has been recognized from a strategic perspective (Taylor \& Groom 1989, Hey 1992). The Intergovernmental Oceanographic Commission (IOC) of UNESCO is encouraging coastal nations to establish national programs for assessing and monitoring coastal ecosystems so as to enhance the ability of national and regional management organizations to develop and implement effective remedial programs for improving the quality 
of degraded ecosystems (IOC 1992). This encouragement is underscored by the United Nations (UN) Conference on Environment and Development (UNCED) declaration on the ocean that recommended that coastal nations of the globe: (1) prevent, reduce, and control degradation of the marine environment so as to maintain and improve its life support and productive capacities; (2) develop and increase the potential of marine living resources to meet human nutritional needs, as well as social, economic, and development goals; and (3) promote the integrated management and sustainable development of coastal areas and the marine environment.

\section{ECOSYSTEM-BASED MANAGEMENT APPROACHES}

The development of strategic approaches to achieving the UNCED ocean goals from the ecosystem perspective is evolving from recent discussion, debate, and reporting. The Ecological Society of America Committee on the Scientific Basis for Ecosystem Management concluded that the overarching principle for guiding ecosystem management is to ensure the intergenerational sustainability of ecosystem goods (e.g. fish, trees, petroleum) and ecosystem services or processes including productivity cycles and hydrological cycles (Christensen et al. 1996). This approach represents a paradigm shift from the highly focused shortterm sector-by-sector resource assessment and management approach in general practice today by natural resource stewardship agencies, to the broader more encompassing ecosystem approach that moves spatially from smaller to larger scales, and from short-term to longer-term management practice (Lubchenco 1994). Included in the new paradigm is a movement from the management of commodities to the sustainability of the productive potential for ecosystem goods and services (Table 1).

This approach builds on an earlier application of 'an ecosystem approach' to management of the Great

Table 1. Some of the substantive changes between traditional resource management and ecosystem management. From Lubchenco (1994)

\begin{tabular}{|ll|}
\hline \multicolumn{2}{|c|}{ Ecosystem management: a paradigm shift } \\
& To \\
\hline Individual species & Ecosystems \\
Small spatial scale & Multiple scales \\
Short-term perspective & Long-term perspective \\
Humans: independent of ecosystems & Humans: integral parts of ecosystems \\
Management divorced from research & Adaptive management \\
Managing commodities & Sustaining production potential for \\
& goods and services \\
\hline
\end{tabular}

Lakes Basin Ecosystem (Great Lakes Science Advisory Board 1978, Duda 1990), and more recent efforts in developing an ecosystem assessment approach for the management of the North Sea (NSQSR 1993, Reid 1999), the Northeast Shelf of the US (Sherman et al. 1996), the Baltic Sea (ECOPS et al. 1995), and the Yellow Sea (Lee \& Sutinen 1999). The ecosystem approach recognizes humankind and economic/social systems as being integral parts of the ecosystem. The Great Lakes approach led to agreements between the US and Canada to follow longer-term pathways for sustainable use of ecological resources. The 2 decades of experience in struggling to operationalize this ecosystem approach have resulted in management programs to reverse the trend in coastal degradation

The new paradigm has relevance to the management of large marine ecosystems (LMEs) (Fig. 1). On a global scale, 50 LMEs produce $95 \%$ of the world's annual marine fishery yields, and within their waters most of the global ocean pollution, overexploitation, and coastal habitat alteration occurs. This phenomenon is discussed to date in $9 \mathrm{LME}$ Volumes (AAAS 1986, 1989, 1990, 1991, 1993, Sherman et al. 1996, 1998, Kumpf et al. 1999, Sherman \& Tang 1999). The LMEs are regions of ocean space encompassing coastal areas from river basins and estuaries out to the seaward boundary of continental shelves and the outer margins of coastal current systems. LMEs are relatively large regions on the order of $200000 \mathrm{~km}^{2}$ or greater, characterized by distinct bathymetry, hydrography, productivity, and trophically dependent populations. The theory, measurement, and modeling relevant to monitoring the changing states of LMEs are imbedded in reports on ecosystems with changing ecological states, and on the pattern formation and spatial diffusion within ecosystems (Holling 1973, Pimm 1984, AAAS 1990, Mangel 1991, Levin 1993, Sherman 1994). In relation to the studies needed to improve the state of knowledge, it should be noted that for 33 of the 50 LMEs retrospective analyses have been conducted on the principal driving forces affecting changes in biomass yields (Table 2).

\section{GLOBAL ENVIRONMENT FACILITY}

In 1990, 2 yr before the Rio Summit on environment and development, the Global Environment Facility (GEF) was established as a pilot program to test new approaches and innovative ways to respond to global environmental challenges in 4 focal areas: (1) climate 


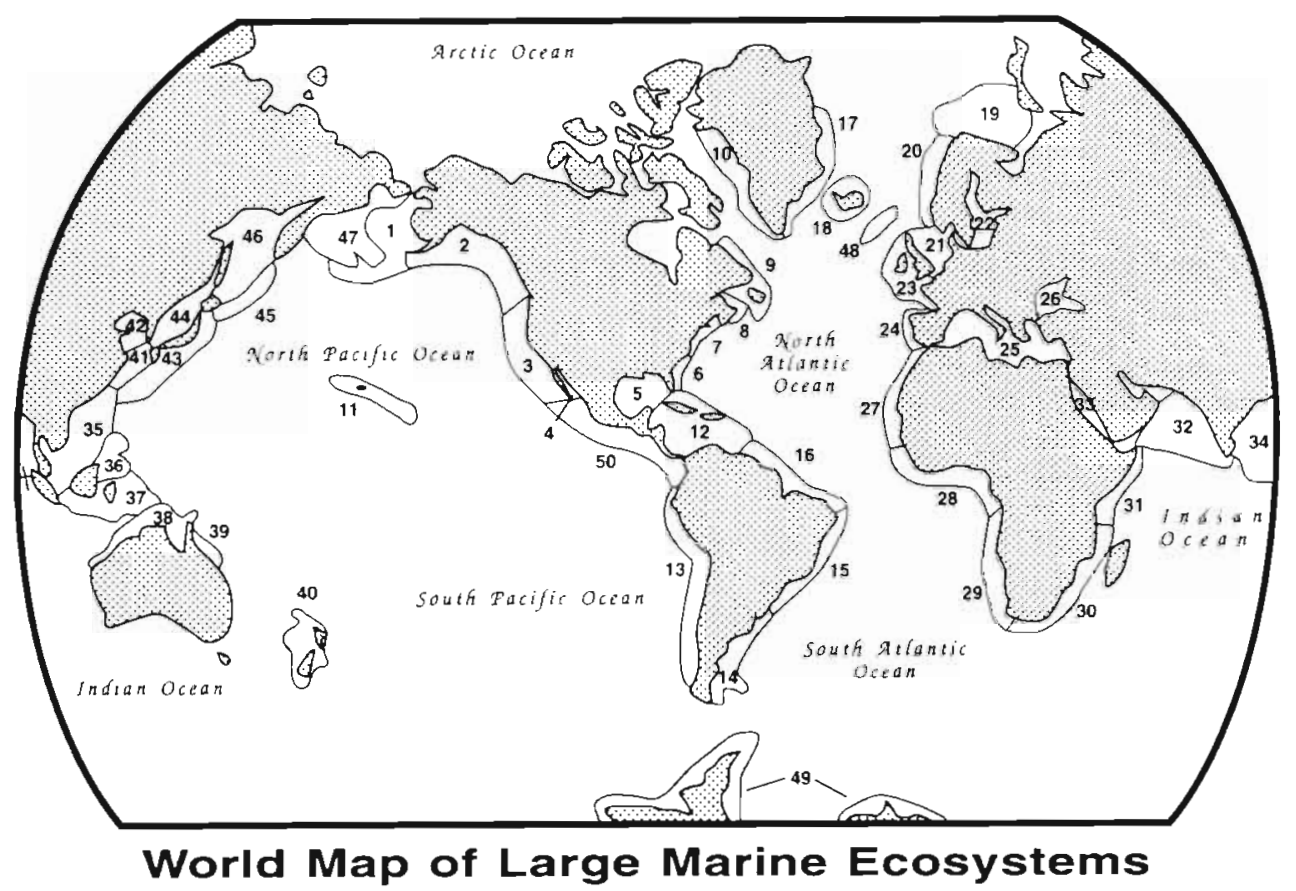

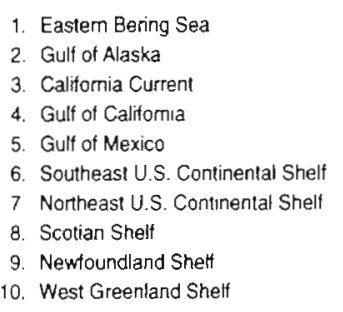

11. Insular Pacific-Hawaiian
12. Caribbean Sea
13. Humboldt Current
14. Patagontan Shelf
15. Brazil Current
16. Northeast Brazll Shelf
17. East Greenland Shelf
18. Iceland Shelf
19. Barents Sea
20. Nonwegian Shelf

21. North Sea
22. Baltic Sea
23. Celtic-Biscay Shelf
24. Iberian Coastal
25. Mediterranean Sea
26. Black Sea
27. Canary Current
28. Gulf of Gunea
29. Benguela Current
30. Agulhas Current

31. Somali Coastal Current
32. Arabian Sea
33. Red Sea
34. Bay of Bengal
35. South China Sea
36. Sulu-Celebes Seas
37. Indonesian Seas
38. Northem Australian Sheff
39. Great Barner Reef
40. New Zealand Shelf

41. East China Sea 42. Yellow Sea

43. Kuroshio Current

44. Sea of Japan

45 Oyashio Current

46. Sea of Okhotsk

47. West Bering Sea

48. Faroe Plateau

49. Antarctic

50. Pactic Central American Coastal

Fig. 1. Boundaries of 50 large marine ecosystems (LMEs)

change, (2) biodiversity conservation, (3) ozone depletion, and (4) international waters. In 1994, the GEF was transformed from its pilot phase into a permanent financial mechanism. Its $\$ 2$ billion trust fund is open to universal participation (currently 161 countries) and builds upon the partnership between the UN Development Programme (UNDP), the UN Environmental Programme (UNEP), and the World Bank - which are its implementing agencies.

In restructuring the GEF, participating governments sought to ensure that it fully embodied the principles that were set out in the UNCED conventions as well as Agenda 21. The GEF serves as a mechanism for international cooperation for the purpose of providing new and additional grants and concessional funding to meet the agreed incremental costs of measures that achieve global environmental benefits. In October 1995, the GEF Council adopted an operational strategy, which represents the strategic framework for actions of the GEF in its 4 focal areas. According to the strategy's principles, the GEF will fund projects and programs that are country-driven and based on national priorities designed to support sustainable development.

Under the GEF Operational Strategy related to international waters, the explicitly stated goal of the project grants is 'to assist countries in the ways that human activities are conducted in the different economic sectors so that the particular coastal/marine waters shared by several countries or a multicountry drainage basin can sustainably support new patterns of human activities' (GEF 1997). Marine-related projects are focused on seriously threatened water bodies including LMEs as an organizing framework. The focus of GEF international water projects is on the most imminent transboundary stressors on ecosystems shared by several countries. Consequently, priority is placed on country-based reforms of sectoral policies and activities responsible for the most serious transboundary environmental problems (GEF 1997). An ecosystem approach to resources development, management, and sustainability in coastal oceans has been adopted by the GEF. The GEF's inter- 
Table 2. List of 33 large manine ecosystems (LMEs) and subsystems for which syntheses relating to primary, secondary, or tertiary driving forces controlling variability in biomass yields have been completed for inclusion in LME volumes

\begin{tabular}{|c|c|c|}
\hline Large marine ecosystem & Volume no & Authors \\
\hline \multirow[t]{2}{*}{ US Northeast Continental Shelf } & 1 & $\begin{array}{l}\text { M. Sissenwine } \\
\text { P. Falkowski }\end{array}$ \\
\hline & 6 & S. Murawski \\
\hline US Southeast Continental Shelf & 4 & J. Yoder \\
\hline \multirow{3}{*}{ Culf of Mexico } & 2 & W. Richards \& M. McGowan \\
\hline & 4 & B. Brown et al. \\
\hline & 9 & R. Shipp \\
\hline \multirow[t]{3}{*}{ California Current } & 1 & A. MacCall \\
\hline & 4 & M. Mullin \\
\hline & 5 & D. Bottom \\
\hline \multirow[t]{2}{*}{ Eastern Bering Shelf } & 1 & L. Incze \& Schumacher \\
\hline & 8 & P. Livingston et al. \\
\hline West Greenland Shelf & 3 & H. Hovgărd \& E Buch \\
\hline Norwegian Sea & 3 & B. Ellersten et al. \\
\hline \multirow[t]{2}{*}{ Barents Sea } & 2 & H. Skjoldal \& F. Rey \\
\hline & 4 & V. Borisov \\
\hline North Sea & 1 & N. Daan \\
\hline Baltic Sea & 1 & G. Kullenberg \\
\hline Iberian Coastal & 2 & T. Wyatt \& G. Perez-Gandaras \\
\hline Mediterramean-Adriatic Sea & 5 & G. Bombace \\
\hline Canary Current & 5 & C. Bas \\
\hline Gulf of Guinea & 5 & D. Binet \& E. Marchal \\
\hline Benguela Current & 2 & R. Crawford et al. \\
\hline Patagonian Shelf & 5 & A. Bakun \\
\hline Caribbean Sea & 3 & W. Richards \& J. Bohnsack \\
\hline South China Sea-Gulf of Thailand & 2 & T. Piyakarnchana \\
\hline East China Sea & 8 & Y.-Q. Chen \& X.-Q. Shen \\
\hline Sea of Japan & 8 & M. Terazaki \\
\hline Yellow Sea & 2 & Q. Tang \\
\hline Sea of Okhotsk & 5 & V. Kusnetsov et al. \\
\hline Humboldt Current & 5 & J. Alheit \& P. Bernal \\
\hline Pacific Central American & 8 & A. Bakun et al. \\
\hline Indonesia Seas-Banda Sea & 3 & J. Zijlstra \& M. Baars \\
\hline \multirow[t]{2}{*}{ Bay of Bengal } & 5 & S. Dwivedi \\
\hline & 7 & A. Hazizi et al. \\
\hline Antarctic Marine & 1 and 5 & R. Scully et al. \\
\hline Weddell Sea & 3 & G. Hempel \\
\hline Kuroshio Current & 2 & M. Terazaki \\
\hline Oyashio Current & 2 & T. Minoda \\
\hline \multirow[t]{3}{*}{ Great Barrier Reef } & 2 & R. Bradbury \& C. Mundy \\
\hline & 5 & G. Kelleher \\
\hline & 8 & J. Brodie \\
\hline Somali Current & 7 & E. Okemwa \\
\hline South China Sea & 5 & D. Pauly \& V. Christensen \\
\hline \multicolumn{3}{|l|}{ Vol. 1 AAAS (1986) } \\
\hline \multicolumn{3}{|l|}{ Vol. 2 AAAS (1989) } \\
\hline \multicolumn{3}{|l|}{ Vol. 3 AAAS $(1990)$} \\
\hline \multicolumn{3}{|l|}{ Vol 4 AAAS (1991) } \\
\hline \multicolumn{3}{|l|}{ Vol. 5 AAAS (1993) } \\
\hline \multicolumn{3}{|l|}{ Vol. 6 Sherman et al. $\{1996\}$} \\
\hline \multicolumn{3}{|l|}{ Vol. 7 Sherman et al. (1998) } \\
\hline \multicolumn{3}{|l|}{ Vol. 8 Sherman \& Tang (1999) } \\
\hline Vol. 9 Kumpf et al. (1999) & & \\
\hline
\end{tabular}

The GEF projects are developed initially in multi-year horizons. In practice some may become decadal projects supported principally by the coastal states. The incremental investments by the GEF are intended to leverage funds contributed by the participating countries and partners in the public and private sectors to initiate and maintain a science-based approach to improve the prospects for achieving long-term sustainability of marine resources. Countries provide 'inkind' national contributions, cash, and policy/institutional reforms to projects, to be augmented by both funds and technical assistance from the more developed donor countries. Many countries, including Canada, Denmark, France, Germany, Japan, Norway, Sweden, the United Kingdom, and the United States, are already heavily engaged in bilateral aid programs with developing countries aimed at improving the marine environment, habitats and fisheries, tourism, mining, and petrogenic energy development.

\section{USE OF MODULAR STRATEGIES FOR ASSESSMENT AND MANAGEMENT}

Sustainability of resources and growth of economies are topics vital to countries in the developing world. Published commentary from scientists in the early 1990s underscores the need for socioeconomic considerations to be an integral part of applying the ecosystem approach to the assessment and management of LMEs across the globe. While some scientists are concerned with the lack of consistent success in the management of marine resources (Ludwig et al. 1993), others stress the utility of science-based assessments as part of marine resource management practices (Rosenberg et al. 1993). These views, while divergent, focus on the importance of introducing improved assessment and management strategies, particularly in developing re-

national waters focal area is assisting recipient countries around the globe in supporting incremental costs for innovative projects to improve the assessment and management of LMEs and increase the socioeconomic benefits to be derived from their resources. gions of the world, including Asia, Africa and Latin America, where coastal ecosystems are of even greater value than in Europe or North America. In these areas subsistence fishing for protein and income must be sustained for the support of coastal societies that have 
few economic alternatives. The degradation of coastal waters in developing countries, as described by Duda \& Cruz (1998), indicates that urgent attention to improved management is necessary.

Given the enormous stress on these ecosystems, management cannot wait for science to catch up with a full understanding of ecosystem structure and function. The best presently available science is needed to assess the effects of changing ecosystem conditions. In both Europe in the North Sea and North America in the northwest Atlantic, scientists have collected information for $40 \mathrm{yr}$ or more describing the decline in ecosystem integrity, but it was just not convincing enough until the later half of the 1990s to reverse government policies encouraging overexploitation. How many decades of data are needed to do so for other continents? Basic information must be collected so that management regimes may be based on sound science. The challenge is how to do this with limited funding, limited capacity, and decision-making under uncertainty, and how best to divide the complex processes of monitoring, assessment, and management into achievable modules for simplicity and applicability.

Toward this goal, a body of experience is being developed in LMEs on practical applications of a modular approach to ecosystem assessment and management. The modules are consistent with the premise of Christensen et al. (1996) that ecosystem management is driven by explicit goals, executed by policies, protocols, and practices, and made adaptable by monitoring and research, based on the best available understanding of the ecological interactions and processes necessary to sustain ecosystem composition, structure, and function. The 5 modules focus on ecosystem (1) productivity, (2) fish and fisheries, (3) pollution and ecosystem health, (4) socioeconomic conditions, and (5) governance.

From a global perspective, information based on the application of the modular strategy can provide a framework for comparative inferences among LMEs as to global changes. Biological and physical processes within the LMEs are reflective of 'internal' dynamics rather than boundary conditions and have proven useful in comparing effects of changing environmental conditions on LMEs in different parts of the globe (Bakun 1993, 1999).

The National Marine Fisheries Service of NOAA has experience in the application of the 5-module LME strategy within the US Northeast Shelf ecosystem. Results have provided substantial evidence of excessive fishing mortality as the principal 'driving force' leading to the depletion of the biomass of cod, haddock, flounder, and other demersal fish stocks (Sissenwine \& Cohen 1991, Murawski 1996). The timeseries information from catch data, bottom trawl surveys, and plankton-productivity surveys when coupled with socioeconomic data and data from NOAA's Status and Trends Program provide evidence of 'overfishing' rather than any environmental regime shift or degraded environment as a major cause for the decline. Although the LME study revealed a growing nearcoast problem of nutrient enrichment and an increasing frequency and extent of harmful algal blooms, the capacity of the ecosystem to produce fish was not diminished for species not subjected to heavily targeted fishing (Sherman et al. 1996). As a result, pelagic stocks of mackerel and herring are at unprecedented high biomass levels estimated at 6 million metric tons (NOAA 1998). Three of the modules that are science based (productivity, fish and fisheries, and pollution and ecosystem health) are designed to produce assessment information on which to recommend management decisions. Related socioeconomic and governance analyses are linked with the assessments to evaluate management options for resource sustainability (Edwards \& Murawski 1996, Murawski 1996).

\section{PRODUCTIVITY MODULE}

Productivity can be related to the carrying capacity of the ecosystem for supporting fish resources (Pauly \& Christensen 1995, Pauly et al. 1998, Williams 1998). Recently it has been suggested that the maximum global level of primary productivity for supporting the average annual world catch of fisheries has been reached, and further large-scale increases in yields of unmanaged fisheries from marine ecosystems are likely to be at the lower trophic levels in the marine food chain (Beddington 1995, Pauly \& Christensen 1995). This appears to be corroborated by changes in the species composition of the catches of fisheries from the East China Sea LME (Chen \& Shen 1999). Measurement of ecosystem productivity can also serve as a useful indication of the growing problem of coastal eutrophication (NSQSR 1993). In several LMEs, excessive nutrient loadings of coastal waters have been related to algal blooms that have been implicated in mass mortalities of living resources, emergence of pathogens (e.g. cholera, vibrios, red tides, paralytic shellfish toxins) and explosive growth of non-indigenous species (Epstein 1996).

The ecosystem parameters measured in the productivity module are zooplankton biodiversity and information on species composition, zooplankton biomass, water column structure, photosynthetically active radiation (PAR), transparency, chlorophyll a, $\mathrm{NO}_{2}, \mathrm{NO}_{3}$, primary production, and environmental variability. The plankton of LMEs can be measured by deploying continuous plankton recorder systems from commer- 
cial vessels of opportunity (Glover 1967). Technically advanced plankton recorder towed bodies can be fitted with sensors for temperature, salinity, chlorophyll, nitrate/nitrite, petroleum, hydrocarbons, light, bioluminescence, and primary productivity (Aiken et al. 1999), providing the means to monitor changes in phytoplankton, zooplankton, primary productivity, species composition and dominance, and long-term changes in the physical and nutrient characteristics of the LME, as well as longer-term changes relating to the biofeedback of the plankton to environmental change (Colebrook 1986, Dickson et al. 1988, Colebrook et al. 1991, Williams 1993).

\section{FISH AND FISHERIES MODULE}

Changes in species composition within the fish communities of LMEs have resulted from (1) excessive exploitation (Sissenwine \& Cohen 1991), (2) shifts in the environmental and/or climate regime (Bakun 1993, 1999) or (3) coastal pollution (Mee 1992, Bombace 1993). These 3 sources of variability in fisheries yield are operable in most LMEs. They can be described as primary, secondary, and tertiary driving forces in fisheries yields, contingent on the ecosystem under investigation. For example, in the Humboldt Current, Benguela Current, and California Current LMEs, the primary driving force influencing variability in fisheries yield and ecosystem productivity is the changing upwelling strength (MacCall 1986, Crawford et al. 1989, Alheit \& Bernal 1993, Bakun 1993). Fishing and pollution effects are secondary and tertiary effects on fisheries yields. In continental shelf LMEs, including the Yellow Sea and Northeast US Shelf, excessive fisheries effort has been the cause of large-scale declines in catch and changes in the biodiversity and dominance in the fish community (Sissenwine 1986, Tang 1993). In these ecosystems, pollution and environmental perturbation are of secondary and tertiary influence. In contrast, significant coastal pollution and eutrophication have been the principal factors driving the changes in fisheries yields of the Northwest Adriatic (Bombace 1993), the Black Sea (Mee 1992), and the near coastal areas of the Baltic Sea (Kullenberg 1986). Overexploitation and natural environmental changes are of secondary and tertiary importance. Changes in the biodiversity of the fish community can generate cascading effects up the food chain to apex predators and down the food chain to plankton components of the ecosystem (Overholtz \& Nicolas 1979, Payne et al. 1990).

The fish and fisheries module includes fisheriesindependent bottom trawl surveys and acoustic surveys for pelagic species to obtain time-series informa- tion on changes in biodiversity and abundance levels of the fish community (Pope 1977, Ntiba 1998). Standardized sampling procedures, when deployed from small calibrated trawlers, can provide important information on diverse changes in fish species. The fish catch provides biological samples for stock assessments, stomach analyses, age, growth, fecundity, and size comparisons (ICES 1991), data for clarifying and quantifying multispecies trophic relationships, and the collection of samples to monitor coastal pollution. Samples of trawl-caught fish can be used to monitor pathological conditions that may be associated with coastal pollution. The trawlers can also be used as platforms for obtaining water, sediment, and benthic samples for monitoring harmful algal blooms, virus vectors of disease, eutrophication, anoxia, and changes in benthic communities.

\section{POLLUTION AND THE ECOSYSTEM HEALTH MODULE}

In several LMEs, pollution has been a principal driving force in changes of biomass yields. Assessing the changing status of pollution and health of the entire LME is scientifically challenging. Ecosystem 'health' is a concept of wide interest for which a single precise scientific definition is problematical. Methods to assess the health of LMEs are being developed from modifications to a series of indicators and indices described by several investigators (Costanza 1992, Karr 1992, Norton \& Ulanowicz 1992, Rapport 1992, Costanza \& Mageau 1999). The overriding objective is to monitor changes in health from an ecosystem perspective as a measure of the overall performance of a complex system (Costanza 1992). The health paradigm is based on the multiple-state comparisons of ecosystem resilience and stability (Holling 1973, 1986, 1993, Pimm 1984, Costanza 1992) and is an evolving concept.

Following the definition of Costanza (1992), to be healthy and sustainable an ecosystem must maintain its metabolic activity level, must maintain its internal structure and organization, and must be resistant to external stress over time and space scales relevant to the ecosystem. These concepts were discussed by panels of experts at 2 workshops convened in 1992 by NOAA (NOAA 1993). Among the indices discussed by the participants were 5 that are being considered as experimental measures of changing ecosystem states and health: (1) biodiversity; (2) stability; (3) yields; (4) productivity; and (5) resilience. The data from which to derive the experimental indices are obtained from time-series monitoring of key ecosystem parameters. An effort to validate the utility of the indices is under development (Solow 1994, Solow \& Sherman 
1997). The ecosystem sampling strategy is focused on parameters relating to the resources at risk from overexploitation, species protected by legislative authority (marine mammals), and other key biological and physical components at the lower end of the food chain (plankton, nutrients, hydrography). The parameters of interest include zooplankton composition, zooplankton biomass, water column structure, PAR, transparency, chlorophyll a, $\mathrm{NO}_{2}, \mathrm{NO}_{3}$, primary production, pollution, marine mammal biomass, marine mammal composition, runoff, wind stress, seabird community structure, seabird counts, finfish composition, finfish biomass, domoic acid, saxitoxin, and paralytic shellfish poisoning (PSP) (Sherman 1994). The experimental parameters selected incorporate the behavior of individuals, the resultant responses of populations and communities, and their interactions with the physical and chemical environment. The selected parameters provide a basis for comparing changing health status within and among ecosystems.

Fish, benthic invertebrates and other biological indicator species are used in the pollution and ecosystem. health module to measure pollution effects on the ecosystem including the bivalve monitoring strategy of 'Mussel-Watch', the pathobiological examination of fish (Goldberg 1976, Farrington et al. 1983, ICES 1988, O'Connor \& Ehler 1991, White \& Robertson 1996) and the estuarine and nearshore monitoring of contaminants in the water column, substrate, and selected groups of organisms. The routes of bioaccumulation and trophic transfer of contaminants are assessed, and critical life history stages and selected food-chain organisms are examined for a variety of parameters that indicate exposure to, and effects of, contaminants. Contaminant-related effects measured include diseases, impaired reproductive capacity, and impaired growth. Many of these effects can be caused by direct exposure to contaminants, or by indirect effects, such as those resulting from alterations in prey organisms The assessment of chemical contaminant exposure and effects on fisheries resources and food-chain organisms consists of a suite of parameters, including biochemical responses that are clearly linked to contaminant exposure coupled with measurements of organ disease and reproductive status that have been used in previous studies to establish links between exposure and effects. The specific suite of parameters measured will cover the same general responses and thus allow for comparable assessment of the physiological status of each species sampled as it relates to chemical contaminant exposure and effects at the individual species and population level (Svanberg 1992, Turgeon et al. 1992, Varanasi et al. 1992). In addition, the implementation of protocols for assessing the frequency and effect of harmful algal blooms (Smayda 1991) and emergent diseases (Epstein 1993) are included in the pollution module.

\section{SOCIOECONOMIC MODULE}

The socioeconomic module is characterized by its emphasis on practical applications of its scientific findings in managing the LME and on the explicit integration of economic analysis including valuations of ecosystem goods and services with the science-based ecosystem structure and function assessments to ensure that prospective management measures are costeffective. Economists and policy analysts will need to work closely with ecologists and other scientists to identify and evaluate management options that are both scientifically credible and economically practical.

Published reports addressing the developing paradigm of ecosystem management based on economic valuations of ecosystem goods and services include the findings of an expert panel of the Ecological Society of America (Christensen et al. 1996), reports by NOAA (Baker 1996, Griffis \& Kimball 1996), reports of the US Congressional Research Service (Lubchenco 1994, Zinn \& Corn 1994), and SIMCOAST modeling efforts of McGlade (1999). Examples of processes, goods, and services expected from healthy ecosystems are listed in Table 3.

Special consideration should be given to improved knowledge of how the natural system generates economic values. Many valuable services provided by natural systems are not traded in markets or included in planning evaluations, so extra care must be made to ensure that they are not sacrificed through ignorance. The services provided by coastal wetlands as nurseries for fisheries, natural pollution filters, and storm buffers are well-known examples that have particular relevance to coastal reclamation activities. Other examples are more subtle, including the importance of predatorprey relationships and the possibility of losing unrecognized 'keystone' species in a valuable ecosystem. Experience indicates that growing economic values on aesthetic and recreational/tourism amenities are to be expected in the LMEs. A variety of sources of economic value arising from the natural diversity of the LME should be identified and assessed in regard to existing uses and potential management innovations (Hoagland et al. 1.999).

Each project should include a generalized characterization of the ways in which human activities affect the natural marine system and the expected 'sensitivity' of these forcing functions to various types and levels of human activity. Population dynamics, coastal development, and land-use practices in the system's drainage basin are clear examples. Work which inte- 
Table 3. Ecosystem goods and services. Healthy ecosystems perform a diverse array of functions that provide both goods and services to humanity. Here, the term goods refers to items given monetary value in the market place, whereas the services from ecosystems are valued, but rarely bought or sold. From Lubchenco (1994)

Ecosystem processes include:

- Hydrologic flux and storage

- Biological productivity

- biogeochemical cycling and storage

- Decomposition

- Maintenance of biological diversity

Ecosystem 'goods' include:

- Food

- Construction materials

- Medicinal plants

- Wild genes for domestic plants and animals

- Tourism and recreation

Ecosystem 'services' include:

- Maintaining hydrological cycles

- Regulating climate

- Cleansing water and air

- Maintaining the gaseous composition of the atmosphere

- Pollinating crops and other important plants

- Generating and maintaining soils

- Storing and cycling essential nutrients

- Absorbing and detoxifying pollutants

- Providing beauty, inspiration, and research

grates the efforts of natural and social scientists should concentrate further on resolving apparent effects (such as eutrophication-associated red tide events or changing fish population structures) that are confounded by cycles or complex dynamics in the natural system itself. Progress is possible, too, in achieving better characterizations of the way in which human forcing is mediated by alternative management options. Emphasis should be placed on isolating and quantifying those forcing activities (sewage discharge, agricultural runoff, fishing effort) likely to be expressed most prominently in effects on the natural system. Other considerations in ecosystem valuation analyses involve tradeoffs in multi-use systems among finfish/shellfish and aquaculture/capture fisheries, as well as various options to be considered in habitat restoration (Levin 1999).

\section{GOVERNANCE MODULE}

The governance module is evolving (Juda 1999, McGlade 1999). Case studies are now underway on ecosystems to be managed from a more holistic perspective in projects supported by the GEF, including the Yellow Sea ecosystem, where the principal effort is underway by the People's Republic of China (Tang 1989) and South Korea (Lee \& Sutinen 1999, Zhang \& Kim 1999), and also the Gulf of Guinea LME by Ivory Coast, Ghana, Nigeria, Benin, Cameroon and Togo (UNIDO 1997). The governments of South Africa, Namibia and Angola are conducting joint assessments of the resources of the Benguela LME to guide the development of a management regime for the shared resources of the ecosystem to ensure their long-term sustainability, particularly with regard to food security. The Great Barrier Reef ecosystem is also being managed from an holistic ecosystem perspective (Bradbury \& Mundy 1989, Kelleher 1993, Brodie 1999) along with the Northwest Australian Continental Shelf ecosystem (Sainsbury 1988) under management by the state and federal governments of Australia, and the Antarctic marine ecosystem under the Commission for the Conservation of Antarctic Marine Living Resources (CCAMLR) and its 21 nation membership (Scully et al. 1986). Movement toward ecosystem management is emerging for the North Sea (NSQSR 1993), the Barents Sea (Eikeland 1992), and the Black Sea (Hey \& Mee 1993). Fisheries assessments are also now being considered within the context of ecosystems management (McGlade 1999).

\section{INTEGRATED MANAGEMENT IN APPLYING THE ECOSYSTEM APPROACH}

A framework is now emerging for linking sciencebased assessments of the changing states of coastal ecosystems to guiding environmentally sound economic development of ecosystem resources and management practices. The framework is being developed through a series of regional efforts aimed at cross-sectoral integration of assessments of coastal productivity, fish and fisheries, and pollution and ecosystem health, with socioeconomics and governance modules (Sutinen et al. 1998). The application and testing of the modules and simplified approaches to the modules are being supported, in part, by grants from the GEF to governments of countries bordering large marine ecosystems in Asia and Africa.

The GEF Operational Strategy (GEF 1997) recommends that countries address their nearshore oceans in a joint manner utilizing LMEs as a framework for analysis, technical assistance, capacity building, and establishment of management regimes. The Operational Strategy recommends that countries undertake a transboundary diagnostic analysis (TDA) to provide the science-based assessments for priority setting on threats to the ecosystem and root causes. It also recommends a process for producing a Strategic Action Program (SAP) of activities to address socioeconomic con- 
siderations as part of improving governance regimes for joint management, intersectoral management nationally, and subnational/community management strategies. GEF is essentially helping countries test the use of simplified modules previously utilized in LMEs and applying them to developing country situations. The modules strengthen the linkage between science and management and facilitate assessment and management of the environments and resources of entire ecosystems including the drainage basins and estuaries that are integral to supporting the diversity of LMEs.

\section{MODEL SYSTEMS}

The Gulf of Guinea LME project was initiated with GEF support in 1995. During the pilot phase from 1995 to 1999, the 6 participating countries (Benin, Cameroon, Ghana, Ivory Coast, Nigeria, and Togo) have used the GEF grant to strengthen national infrastructure in staffing positions and engaging non-government support. A network of 250 people is engaged in implementing the project. Among the successfully completed activities is a cooperative survey of the bottom fish stocks using a chartered Nigerian vessel with representatives of each of the participating countries taking part in the trawling and data reporting operations. Funds were used to complete a report on the major multidecadal shifts in the abundance of fish stocks in the ecosystem, caused principally by environmental perturbations affecting the annual upwelling cycle and temperature regime of the ecosystem (Fig. 2). In addition to the cooperative trawl survey, surveys of the plankton community of the Gulf of Guinea are conducted at $6 \mathrm{wk}$ intervals using plankton recorder systems deployed from large container vessels transiting the region. The samples are being processed in a plankton center established with GEF funds in Tema, Ghana, in collaboration with the Sir Alister Hardy Foundation of the UK.

Restoration of mangrove areas along the coast and assessments of the principal sources of coastal pollution have been initiated. Plans for the management of transboundary coastal resources have been completed by each of the countries (Ceda 1997. Adam 1998, Ibe 1998a, Ibe \& Zabi 1998, Mondjanagni et al. 1998a,b). Several studies have suggested options for increasing the long-term sustainability of coastal resources and increasing socioeconomic benefits to the people of the region (Ibe et al. 1998). An Accra declaration has been signed by the environmental ministers from each of the 6 countries indicating joint intentions for taking steps to promote the long-term sustainability of the Gulf of Guinea resources (Ibe 1998b).

Operational methodologies are being developed to ensure that near coastal and drainage basin effects on the LME proper are included in the overarching strategy for a systems approach to management encompassing (1) drainage basin, (2) near coastal, and (3) offshore coastal components of the LME.

Two model systems being adapted for filling this pressing need for improved assessment strategies are: the Batangas Bay model in the Philippines and the Xiamen Municipality model in China. Both models were developed as demonstration projects in Integrated Coastal Management (ICM) as part of the GEF-funded Regional Program for the Prevention and Management

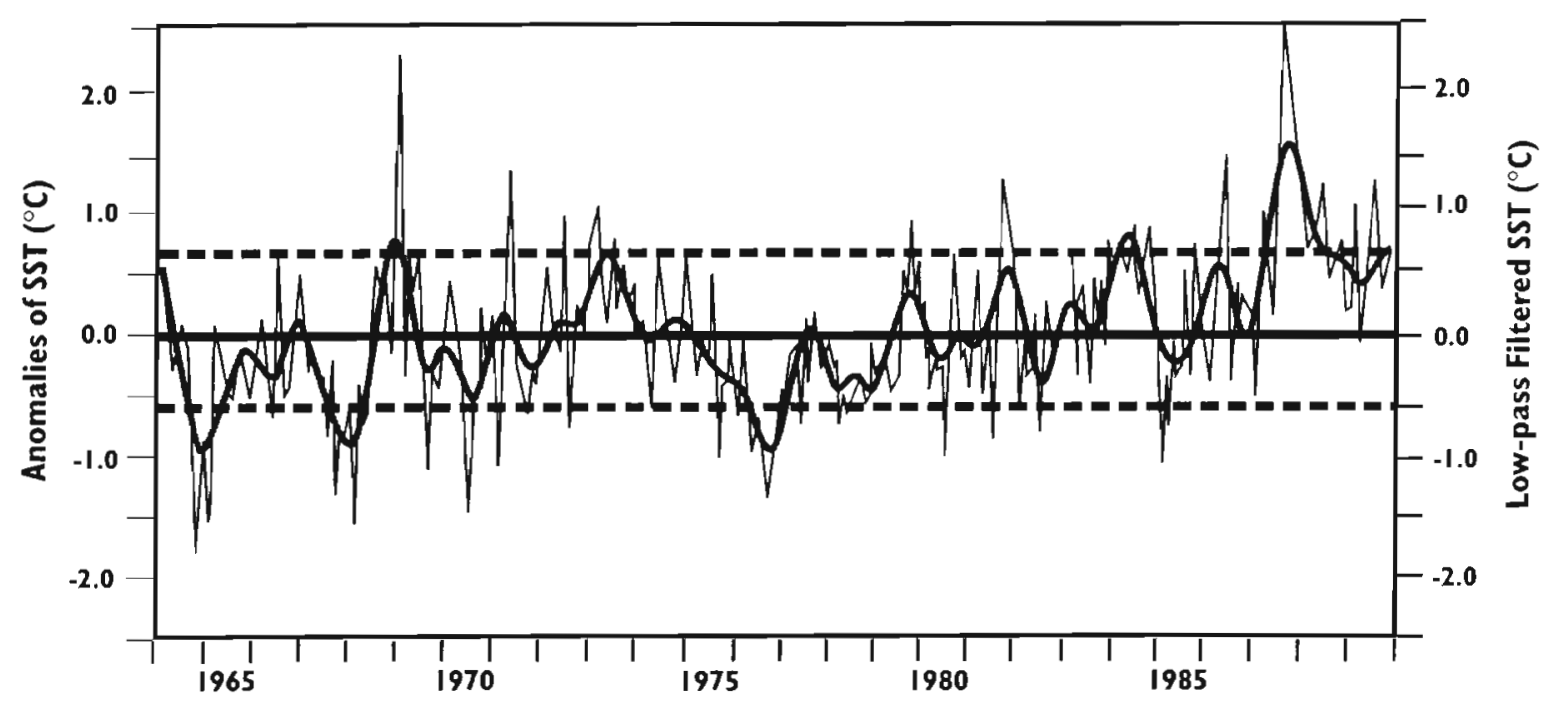

Fig. 2. Sea-surface temperature anomalies for 1964 to 1990 from ship of opportunity data in the area 2 to $8^{\circ} \mathrm{W}, 4^{\circ} \mathrm{N}$ to the coast. $(\longrightarrow)$ Monthly anomalies $\left({ }^{\circ} \mathrm{C}\right)$; (—) filtered anomalies $>12$ mo. From Binet \& Marchal (1993) 
of Marine Pollution in the East Asian Seas (PG-ENRO 1996). The approach provides a framework for management of the coast of the Batangas Bay region of the Province of Batangas in the Philippines. It includes guidelines for the implementation of a core program of: (1) integrated waste management, (2) water pollution abatement, (3) habitat improvement, (4) conservation of stressed mangrove and coral reef areas, (5) coastal tourism development, and (6) improvements of the municipal fisheries (PG-ENRO 1996). The linkage between LMEs and ICM activities will be implemented as a demonstration of a Fast Track-ICM/LME project to be conducted around the margins of the Yellow Sea by China and Korea.

Another example of the interest expressed for planning and implementing GEF international waters projects is under development for the Benguela Current LME by Angola, Namibia, and South Africa. These countries are completing a synthesis and assessment of information on fisheries, environmental variability, offshore oil and gas exploration and production, marine diamond mining, coastal zone developments and socioeconomics as well as a 12 mo study of transboundary issues to be addressed over the next $5 \mathrm{yr}$. Among the issues of particular concern are the largescale variability in upwelling events affecting the abundance of pelagic fisheries (Fig. 3), and the conflicts between marine diamond mining and rock lobster fishing interests in South Africa and Namibia over the use of near-coastal shelf areas. It is now technically feasible to conduct mining operations from specially equipped vessels up to $14 \mathrm{~km}$ offshore. Areas traditionally fished for lobster are close to the coast within $5 \mathrm{~km}$. However, lobster populations migrate offshore into deeper water during certain months, and hence are vulnerable to mining impacts. Resolutions for resolving actual and potential conflicts are being

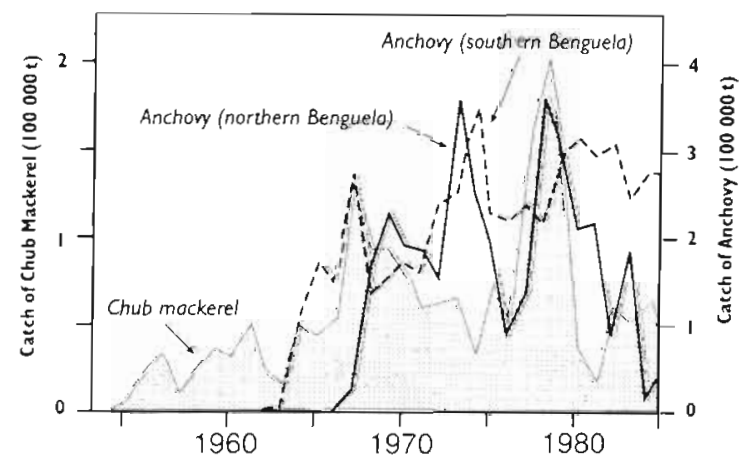

Fig. 3. Catches of the anchovy Engraulis japonicus from northern Benguela and southern Benguela, and of the chub mackerel Scomber japonicus from the Benguela Current LME. From Crawtord et al. (1989) addressed by the government agencies serving as resource stewards and representatives of the diamond and fishing industries. Similar conflicts between artisanal fisheries and large-scale commercial operations are high on the priority list for resolution of transboundary problems. Planning for the project is following along the lines of transboundary issues for resolution including: (1) environmental and productivity forecasting, (2) fish and fisheries sustainability, and (3) pollution and ecosystem health improvement issues (UNDP 1999a).

Cutting across each of the issues are analyses addressing socioeconomic benefits to be derived from a long-term strategy for encouraging resource sustainability. Other considerations are being given to improving resource sustainability measures through examination of various governing bodies implementing management regimes for shared transboundary fishing resources. The probability for success in moving toward management regimes that promote longterm resource sustainability is enhanced by the engagement of the 3 countries (Angola, Namibia, South Africal in cooperative science-based assessments of the changing states of the Benguela Current LME. Joint activities will include developing better predictions of environmental events, improved systems for producing annual resource assessments, sharing results, and providing advice to governments on options for improving fish and fisheries resource development, use, and sustainability (Fig. 4).

\section{COMPLEMENTARITY AMONG INTERNATIONAL AGREEMENTS}

Fundamental global norms for conservation of marine resources and preservation and protection of the marine environment are established in the UN Convention on the Law of the Sea (UNCLOS), which entered into force in 1994. Detailed rules and standards at the global level exist to control pollution from ships, including at-sea disposal of wastes, and for whales (International Whaling Commission 1994), the one fishery whose target species truly migrate worldwide. Otherwise, the rules on marine pollution and fisheries are regional, in keeping with the scale of LMEs.

It is critical to appreciate and make use of the complementarity between general global conventions and norms and specialized agreements of a geographic or activity-specific nature. Global norms, through general principles and objectives, establish parameters for all national and collective action. These are translated into more specific goals and country-specific commitments through specialized agreements. Recognizing the need 


\section{GENERIC ROOT CAUSES}

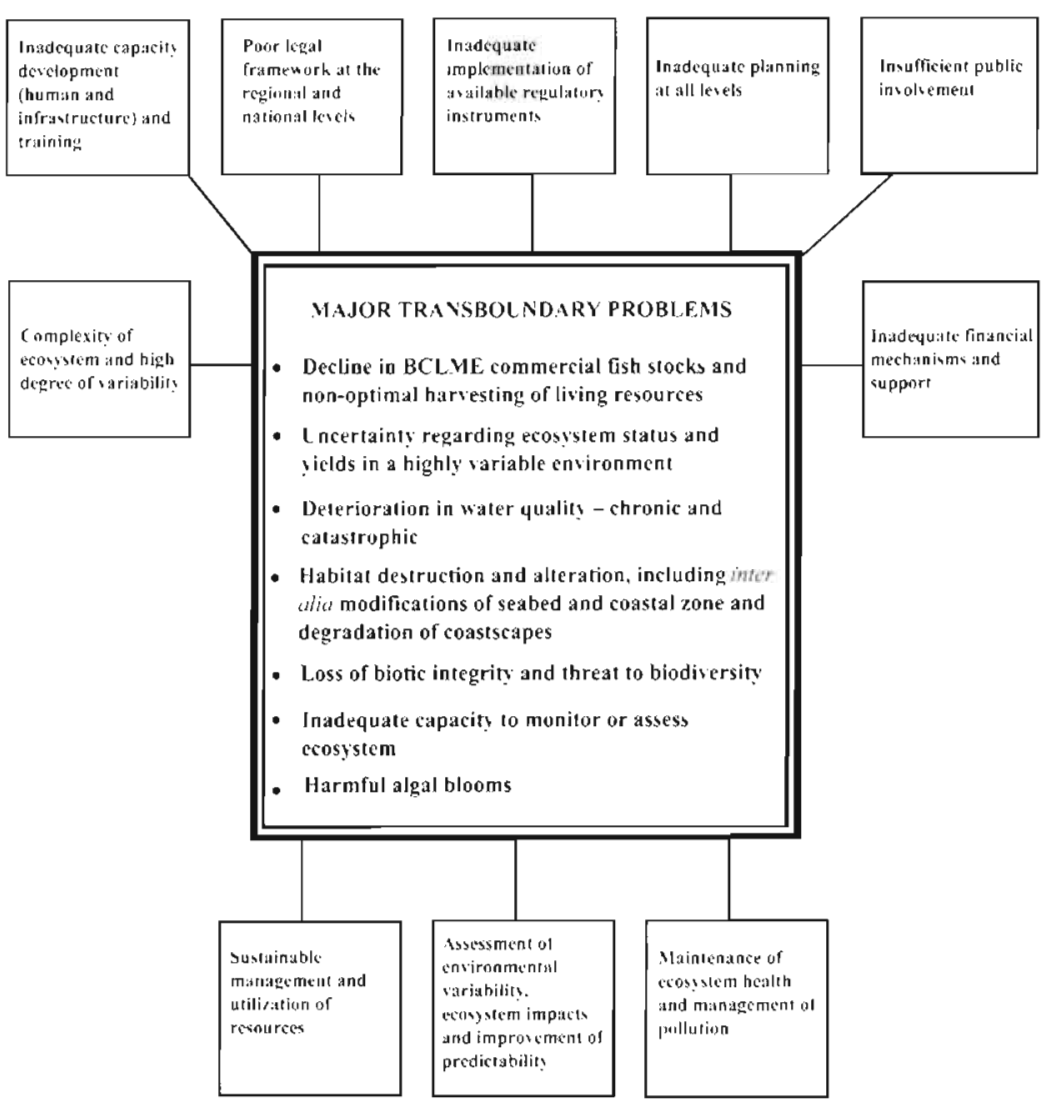

AREAS WHERE ACTION IS REQUIRED

Fig. 4. Major transboundary problems, generic root causes and areas requiring action in the Benguela Current LME (BCLME). From UNDP (1999b)

based activities. The GPA includes a comprehensive approach to addressing coastal degradation that has at its source land activities and it should help spur nations to adopt new institutional arrangements linking freshwater basin management with downstream marine and coastal impacts, such as the revised 1996 protocol on land-based activities for the Mediterranean Sea. This linkage is reinforced by the 1997 UN Convention on the Law of Non-Navigational Uses of International Watercourses.

Another example of the relationship between global frameworks and specialized agreements may be found in recent fisheries developments. A call for selective fishing gear and practices and a precautionary approach to fisheries management at the global level was included in the 1995 UN Agreement on Straddling Fish Stocks and Highly Migratory Fish Stocks. Implementing the UNCLOS leverages their application and elaboration in particular regional fisheries agreements. As specific improvements are developed and applied at national and regional levels they may be adopted elsewhere and provide the basis for agreement on more detailed global rules.

Existing international agreements go only part of the way toward attaining the goal of comprehensive prob-

to respond to site-specific circumstances and the particular mix of problems in a given water body, specific geographic instruments provide a means to determine priorities and comprehensively address them. At the operational level, these problems may be segmented into more manageable units, and agreement on specialized technical and policy response options promotes harmonized approaches among countries.

Thus, for land-based sources of marine pollution, which include pollution borne to the sea by rivers, the UNCLOS framework calls on governments to elaborate more detailed rules and guidelines and to harmonize policies at the regional level to account for regional differences (Articles 207 and 213). Six regional sea conventions have specific agreements on landbased pollution.

In late 1995, the world community took one step further toward the restoration of coastal ecosystems by establishing the Global Programme of Action (GPA) for the protection of the marine environment from land- lem diagnosis and specialized solutions. Those concerning freshwater systems rarely integrate water quality with predominant water allocation concerns, nor do they embody the idea of allocating water for environmental services, such as groundwater recharge or freshwater flow to maintain downstream ecosystems. The 1997 UN Watercourse Convention now remedies this situation in principle, but application at the level of specific transboundary agreements is yet to come. The regional marine agreements for the most part have not linked consideration of pollution with habitat modification and international fisheries.

The North Sea is a major exception, where an integrated assessment is undertaken by a special task force in order to inform regular inter-ministerial conferences (NSTF 1991, NSQSR 1993). Recent developments in the Mediterranean are encouraging, and initiatives in the Baltic have added overfishing, endangered species/ habitat, and genetic loss of wild fish stocks to an agenda once focused exclusively on pollution. In fact, 
the GEF Operational Strategy was developed with the experience of these 3 seas in mind, and several GEFfunded initiatives aim at linking freshwater pollution input, habitat and fisheries in LMEs (e.g. Baltic, Black Sea-Danube Basin, Patagonia Shelf-Plata Basin).

A common global understanding of how to approach complex international waters issues has been developed incrementally over the last 2 decades. Some solutions are worked out sectorally at the global level, such as ship-related pollution, general policies on wetlands, or movement and disposal of hazardous chemicals. Others are handled more comprehensively on a sitespecific regional basis. While the conventions spell out norms, targets, and measures to be applied, action plans and programs define operational strategies. The intent of UNCLOS, the GPA, and the 1997 Watercourse Convention is for the global solution to be implemented piece by piece in logical, site-specific, regional cooperative efforts as, for example, in the North Sea and the Rhine basin, or for Lake Geneva, the Danube and the Black Sea, and the Wider Caribbean, as well as the Senegal River and the Canary Current LME.

Non-binding soft law complements binding legal arrangements, helping countries overcome barriers to action. Examples range from Agenda 21 Chapters 17 and 18 and the GPA to the action program for Small Island Developing States. The great value of non-binding documents is that they work around the edges of binding commitments to elaborate, guide, and influence action. They may provide a more detailed blueprint, and they may sow the seeds of future binding commitments (Belsky 1992).

Completing this common global understanding are important links to other global framework conventions such as the Convention on Biological Diversity, the UN Framework Convention on Climate Change, and the UN Commission on Sustainable Development. In fact. as recognized by the GEF Council, these initiatives provide a new opportunity for cooperating nations to link many different programs and instruments into regional comprehensive approaches to address international waters. Joint multi-country initiatives tackling transboundary freshwater, coastal, and marine issues are essential for achieving the goals of these important conventions

\section{NORTH-SOUTH COOPERATION}

The world community has at least 3 decades of experience in Europe and North America with regional conventions on transboundary water and environmental issues. Joint activities to address water quantity disputes go back even further. Valuable lessons-positive and negative-have also been learned in the southern hemisphere, some of which are noted in a World Bank funded review of African river basin organizations (Rangeley et al. 1994). With GEF support, the southern hemisphere is contributing new experience through multi-country initiatives focused on site-specific priorities in shared freshwater basins, coastal zones, and LMEs.

Experiences from these joint regional activities suggest several lessons:

- Donor-driven rather than country-driven institutional arrangements have proved ineffective and recipient countries must take ownership of activities.

- Water quality must be considered together with water quantity and ecological considerations in any sectoral development project if sustainable development is to be achieved.

- Ecosystem-based approaches, which encompass overfishing, habitat loss, and biological diversity issues in addition to water quality/pollution abatement, are needed for improving management of transboundary water systems.

- Interministerial and subnational government involvement is necessary in these joint, multi-country regional initiatives if actual changes in sectoral activities causing the transboundary problems are to be achieved.

This growing body of experience also demonstrates that facilitators or third parties are often necessary to bring nations together to address the issues, help them establish a realistic list of priorities on a strategic, waterbody basis, attract international community attention and a coordinated response, and keep the initiative from becoming bogged down. Facilitators may be strong voices in academic or NGO communities or those in donor or international finance institutions who can provide funding for multi-country cooperation.

\section{SUSTAINING COASTAL OCEANS}

The degradation of our planet's water ecosystems is no surprise. Over the years, more and more information on the declining status of freshwater and marine biodiversity has become available. What is new is that the situation has declined so much in both the northern hemisphere and the southern hemisphere that continued economic and social benefits from these systems are at risk. Gradually, shared river basins, coastal areas, and LMEs have become degraded and benefits they have provided may not be sustained into the future. Gradually, national problems are growing into larger ones to the point where they become regionally and globally significant.

The rush by countries to exploit fish stocks by oversubsidizing industrial fishing fleets is socially, economically, and environmentally unsustainable and places 
the future of fishing communities at risk. The global economy spends $\$ 124$ billion each year to land $\$ 70$ billion worth of fish (Duda \& Cruz 1998). The fish stocks in many LMEs are in drastic decline, with 3 quarters of marine fisheries fully fished, overexploited, depleted, or slowly recovering from collapse, and $95 \%$ of these fish are caught in the 50 LMEs that encircle the earth's continents. Open access without effective management regimes means that too many modern boats are chasing too few fish as the profit motive overshadows the collective good. This feeds tendencies to overfish, under-report the catch, and poach.

Even with modernization of fleets and the marine equivalent of 'forest clearcutting', the world's fish catch per person has declined from peaks in the $1980 \mathrm{~s}$ to the levels of the 1960 s, before the great fleet modernization occurred (GEF 1998). The decline in fish stocks since 1983 is evident, with the increase in total catch coming from a few low-value species that are used for feed and fertilizer instead of direct human consumption. Over $40 \%$ of the world catch is inefficiently converted to oil and meal to feed livestock, poultry, and cultivated fish; subsidized fleets fish lower and lower on the food chain with adverse ecosystem impacts on biodiversity. This global environment problem promises to penetrate societies dependent on coastal and marine ecosystems, and its transboundary aspects are growing. Stocks are being harvested by more than one country's fleet. The importance of migratory fish stocks is increasingly apparent, with at least $75 \%$ of the global marine fish catch spending all or part of their life cycles in near-shore waters (Duda \& Cruz 1998).

The call has gone out through global and regional treaties to adopt new joint management regimes so that sustainability of our marine resources can be assured for future generations. Simplified approaches are necessary where information and management capacity are inadequate. An LME-integrated coastal management approach now being tested in Asian coastal waters is a response to this need (Sherman 1998). In addition, the GEF Operational Strategy and its support for the 10 projects related to LMEs in the developing world place a premium on mobilizing sound science to provide information for improved management practices.

The transboundary analysis used by the GEF can simply be framed as the productivity, fish/fisheries, and pollution/ecosystem health modules used for LMEs in North America. Likewise, the SAPs focus on the socioeconomic and governance modules for LMEs. These modules are important. They serve to leverage country commitments for implementing necessary policy, legal, and institutional reforms so that socioeconomic benefits from environmental services of the ecosystem can be sustained for future generations.
Once again, science-based assessments have a role as the governance mechanism utilizes monitoring/assessment modules to ensure programs and policies are sustaining the marine resources.

Pilot efforts are underway to determine the effectiveness of the simplified modules necessary to sustain LMEs in developing nations, particularly those bordering the Gulf of Guinea, Benguela Current, and Yellow Sea. With the post-UNCED recognition of global environmental degradation, it is time for a renewed national impetus to address the sustainability and development of marine resources and ecosystems. It is now incumbent on industrial nations, international finance institutions, and the UN system to take leadership in forming new partnerships among governments, business interests, academia, and the public, to make the necessary reforms and to provide incentives to resolve their transboundary problems. Their responsibility does not end there. They will be called on to provide additional finance and technology to catalyze the participation of developing nations in sustaining transboundary marine resources as part of UNCED's global commitment to sustainable development.

\section{LITERATURE CITED}

AAAS (1986) Variability and management of large marine ecosystems. AAAS Selected Symposium 99. Westriew Press, Inc, Boulder, CO

AAAS (1989) Biomass yields and geography of large marine ecosystems. AAAS Selected Symposium 111. Westview Press, Inc, Boulder, CO

AAAS (1990) Large marine ecosystems: patterns, processes and yields. AAAS Symposium. AAAS Press, Washington, DC

AAAS (1991) Food chains, yields, models, and management of large marine ecosystems. Westview Press, Inc, Boulder, $\mathrm{CO}$

AAAS (1993) Large marine ecosystems: stress, mitigation, and sustainability. AAAS Symposium. AAAS Press, Washington, $\mathrm{DC}$

Adam KS (1998) Towards integrated coastal zone management in the Gulf of Guinea: a framework document. Les Editions du Flamboyant, Cotonou

Aiken J, Pollard R, Williams R, Griffiths G, Bellan I (1999) Measurements of the upper ocean structure using towed profiling systems. In: Sherman $K$, Tang $Q$ (eds) Large marine ecosystems of the Pacific Rim: assessment, sustainability, and management. Blackwell Science, Inc, Malden, MA, p 346-362

Alheit J, Bernal P (1993) Effects of physical and biological changes on the biomass yield of the Humboldt Current ecosystem. In: Sherman K, Alexander LM, Gold BD (eds) Large marine ecosystems: stress, mitigation, and sustainability. AAAS Symposium. AAAS Press, Washington, DC, p 53-68

Baker DJ (1996) What do ecosystem management and the current budget mean for federally supported environmental research? Ecol Appl 6(3):712-715

Bakun A (1993) The California Current, Benguela Current and 
Southwestern Atlantic Shelf ecosystems: a comparative approach to identifying factors regulating biomass yields. In: Sherman K, Alexander LM, Gold BD (eds) Large marine ecosystems: stress, mitigation and sustainability. AAAS Symposium. AAAS Press, Washington, DC, p 199-221

Bakun A (1999) A dynamic scenario for simultaneous regimescale marine population shifts in widely separated large marine ecosystems of the Pacific. In: Sherman $\mathrm{K}$, Tang $\mathrm{Q}$ (eds) Large marine ecosystems of the Pacific Rim: assessment, sustainability, and management. Blackwell Science, Inc, Malden, MA, p 2-26

Beddington JR (1995) The primary requirements. Nature 374 : 213-214

Belsky MH (1992) Interselationships of law in the management of large marine ecosystems. In: Sherman K, Alexander LM, Gold BD (eds) Large marine ecosystems: patterns, processes, and yields. AAAS Symposium. AAAS Press, Washington, DC, p 224-233

Binet D, Marchal E (1993) The large marine ecosystem of shelf areas in the Gulf of Guinea: long-term variability induced by climatic changes. In: Sherman K, Alexander LM, Gold BD (eds) Large marine ecosystems: stress, mitigation, and sustainability. AAAS Symposium. AAAS Press, Washington, DC, p 104-118

Boesch DF (1998) An ecosystem approach: drainage basin and coastal sea as a whole system. Synthesis. In: Proceedings of the Stockholm Water Symposium of 10-15 August 1997. With rivers to the sea: interaction of land activities, fresh water and enclosed coastal seas. Joint Conference, 7 th Stockholm Water Symposium, 3rd International Conference on the Environmental Management of Enclosed Coastal Seas (EMECS). Stockholm International Water Institute (SIWI), Stockholm, p 149-150

Bombace G (1993) Ecological and fishing features of the Adriatic Sea. In: Sherman K, Alexander LM, Gold BD (eds) Large marine ecosystems: stress, mitigation, and sustainability. AAAS Symposium. AAAS Press, Washington, DC, p $119-136$

Bradbury RH, Mundy CN (1989) Large-scale shifts in biomass of the Great Barrier Reef ecosystem. In: Sherman K, Alexander LM (eds) Biomass yields and geography of large marine ecosystems. AAAS Selected Symposium 111. Westview Press, Inc, Boulder, CO, p 143-167

Brodie J (1999) Management of the Great Barrier Reef as a large marine ecosystem. In: Sherman $K$, Tang $Q$ (eds) Large marine ecosystems of the Pacific Rim: assessment, sustainability, and management. Blackwell Science, Inc, Malden, MA, p 428-437

Ceda (Center for Environment and Development in Africa) 1997. Coastal profile of Nigeria. Ceda, Cotonou

Chen Y, Shen X (1999) Changes in the biomass of the East China Sea ecosystem. In: Sherman K, Tang Q (eds) Large marne ecosystems of the Pacific Rim: assessment, sustainability, and management. Blackwell Science, Inc, Malden, MA, p 221-239

Christensen NL, Bartuska AM, Brown JH, Carpenter S, D'Antonio C, Francis R, Franklin JF, MacMahon JA, Noss RF, ParsonsDJ, Peterson CH, Turner MG, Woodmansee RG (1996) Report of the Ecological Society of America committee on the scientific basis for ecosystem management. Ecol Appl 6(3):665-691

Colebrook JM (1986) Environmental influences on long-term. variability in marine plankton. Hydrobiologia 142:309-325

Colebrook JM, Warner AJ, Proctor CA, Hunt HG, Pritchard P, John AWG, Joyce D, Barnard R (1991) 60 years of the continuous Plankton Recorder Survey: a celebration. The Sir Alister Hardy Foundation for Ocean Science, Plymouth
Costanza R (1992) Toward an operational definition of ecosystem health. In: Costanza R, Norton BG. Haskell BD (eds) Ecosystem health: new goals for environmental management. Island Press, Washington, DC, p 239-256

Costanza R, Mageau M (1999) What is a healthy ecosystem? In: Sherman K, Kumpf $H$, Steidinger $\mathrm{K}$ (eds) The Gulf of Mexico large marine ecosystem: assessment, sustainability, and management. Blackwell Science, Inc, Malden, MA, p 385-415

Crawford RJM, Shannon LV, Shelton PA (1989) Characteristics and management of the Benguela as a large marine ecosystem. In: Sherman K, Alexander LM (eds) Biomass yields and geography of large marine ecosystems. AAAS Selected Symposium 111. Westview Press, Inc, Boulder, CO. p 169-219

Dickson RR, Kelly PM, Colebrook JM, Wooster WS, Cushing DH (1988) North winds and production in the eastern North Atlantic. J Plankton Res 10:151-169

Duda AM (1990) Cross-media management of toxic pollutants in the Great Lakes Basin ecosystem. In: Mc Neil RY, Windsor JE (eds) Innovations in river basin management. Canadian Water Resources Association, Cambridge, Ontario, p $321-333$

Duda AM, Cruz CJ (1998) Partnerships to sustain international waters. In: Swift SD (ed) Valuing the global environment: actions and investments for a 21st century. Global Environment Facility, Washington, DC, p 110-133

ECOPS, ESF, European Commission DG XII, and Institute for Baltic Sea Research (1995) Joint Baltic Sea ecosystem studies: a science plan for an interdisciplinary ecosystem analysis in the Baltic Sea. Report of 4 International Baltic Sea Workshops-18-19 March 1993, 4-10 November 1993, 6-8 June 1994, and 22-25 January 1995 Helcom, Helsinki

Edwards SF, Murawski SA (1996) Potential benefits from efficient harvest of New England groundfish. In: Sherman K, Jaworski NA, Smayda TJ (eds) The Northeast Shelf Ecosystem: assessment, sustainability, and management. Blackwell Science, Inc, Cambridge, MA, p 511-526

Eikeland PO (1992) Multispecies management of the barents sea large marine ecosystem: a framework for discussing future challenges. The Fridtjof Nansen Institute, Polhogda, Lysaker

Epstein PR (1993) Algal blooms and public health. World Resour Rev 5(2):190-206

Epstein PR (1996) Emergent stressors and public health implications in large marine ecosystems: an overview. In: Sherman K, Jaworski NA, Smayda TJ (eds) The Northeast Shelf Ecosystem: assessment, sustainability, and management. Blackwell Science, Inc, Cambridge, MA, p 417-438

Farrington JW, Goldberg ED, Risebrough RW, Martin JH, Bowen VT (1983) US 'Musselwatch' 1976-1978: an overview of the trace metal, DDE, PCB, hydrocarbon and artificial radionuclide data. Environ Sci Technol 17:490 - 496

FAO (Food and Agricultural Organization of the United Nations) (1995) FAO yearbook: fishery statistics: catches and landings. fisheries Series no. 48, Statistics Series no 134, Vol 80. FAO. Fisheries Dept, Rome

GEF (Global Environment Facility) (1997) GEF Operational Programs. Global Environment Facility, Washington, DC

GEF (1.998) Valuing the global environment: actions and investments for a 21st century. Giobal Environment Facility. Washington, DC

Glover RS (1967) The continuous plankton recorder survey of the North Atlantic. Symp Zool Soc Lond 19:189-210

Goldberg ED (1976) The health of the oceans. UNESCO Press, Paris 
Great Lakes Science Advisory Board (1978) The ecosystem approach. Scope and implications of an ecosystem approach to transboundary problems in the Great Lakes Basin: special report to the International Joint Commission. Great Lakes Science Advisory Board, Washington, $D C$

Griffis RB, Kimball KW (1996) Ecosystem approaches to coastal and ocean stewardship. Ecol Appl 6(3):708-711

Hedin L (1998) From landscapes to the sea: challenges to understanding how humans influence aquatic ecosystems. In: Proceedings of the Stockholm Water Symposium of 10-15 August 1997. With rivers to the sea: interaction of land activities, fresh water and enclosed coastal seas. Stockholm International Water Institute (SIWI), Stockholm, p 33-45

Hey E (1992) A healthy North Sea ecosystem and a healthy North Sea fishery: two sides of the same regulation? Ocean Dev Int Law 23:217-238

Hey E, Mee LD (1993) Black Sea. The ministerial declaration: an important step. Environ Pollut Law 2315:215-217, $235-236$

Hoagland P, Jin D, Thunberg E, Steinback S (1999) Economic activity associated with the Northeast Shelf large marine ecosystem: application of an input-output approach. Marine Policy Center, Woods Hole Oceanographic Institution and Social Sciences Branch, NEFSC/NMFS, Woods Hole, MA

Holling CS (1.973) Resilience and stability of ecological systems. Institute of Resource Ecology, University of British Columbia, Vancouver

Holling CS (1986) The resilience of terrestrial ecosystems: local surprise and global change. In: Clark WC, Munn RE (eds) Sustainable development of the biosphere. Cambridge University Press, London, p 292-317

Holling CS (1993) Investing in research for sustainability. Ecol Appl 3:552-555

Ibe $C$ (ed) (1998a) Perspectives in integrated coastal areas management in the Gulf of Guinea. Center for Environment and Development in Africa (Ceda), Cotonou, Ibe C (Regional Coordinator) (1998b) GOG LME Newsletter, No. 8, 10/97-3/98. Centre de Recherches Oceanologiques, Abidjan, Ibe C, Zabi SG (eds) (1998) State of the coastal and marine environment of the Gulf of Guinea. Center for Environment and Development in Africa (Ceda), Cotonou

Ibe C, Oteng-Yeboah AA, Zabi SG, Afolabi D (eds) (1998) Integrated environmental and living resources management in the Gulf of Guinea: the large marine ecosystem approach. Proceedings of the 1st Symposium on GEF's LME Project for the Gulf of Guinea. Abidjan 26-30 January 1998. Institute for Scientific and Technological Information, CSIR, Accra

ICES (1988) Results of the 1985 baseline study of contaminants in fish and shellfish. Cooperative Research Report No. 151. ICES, Copenhagen

ICES (1991) Report of the multispecies assessment working group. ICES, CM 1991/Assess 7

International Whaling Commission (1994. The revised management procedure (RMP) for baleen whales. Rep Int Whal Comm 44:145-152

IOC (International Oceanographic Commission of UNESCO) (1992) Global Ocean Observing System (GOOS). An initiative of the Intergovernmental Oceanographic Commission (of UNESCO). IOC. UNESCO, Paris

Juda L (1999) Consideration in developing a functional approach to the governance of large marine ecosystems. Ocean Dev Int Law 30(2):89-125
Karr J (1992) Ecological integrity: protecting earth's life support systems. In: Costanza R, Norton BG, Haskell BD (eds) Ecosystem health: new goals for environmental management. Island Press, Washington, DC, p 223-228

Kelleher G (1993) Sustainable development of the Great Barrier Reef as a large marine ecosystem. In: Sherman $K$, Alexander LM, BD Gold (eds) Large marine ecosystems stress, mitigation, and sustainability. AAAS Symposium. AAAS Press, Washington, DC, p 272-279

Kullenberg $G$ (1986) Long-term changes in the Baltic Ecosystem. In: Sherman K, Alexander LM (eds) Variability and management of large marine ecosystems. AAAS Selected Symposium 99. Westview Press, Inc, Boulder, CO, p 19-32

Kumpf $H_{1}$, Steidinger K, Sherman K (eds) (1999) The Gulf of Mexico large marine ecosystem: assessment, sustainability, and management. Blackwell Science, Inc, Malden, MA

Lee SG, Sutinen JG (1999) Large marine ecosystems, socieconomic and governance: implications for Korea. Korea Obs $30\{1\}: 9-58$

Levin SA (1993) Approaches to forecasting biomass yields in large marine ecosystems. In: Sherman $\mathrm{K}$, Alexander LM. Gold BD (eds) Large marine ecosystems: stress, mitigation, and sustainability. AAAAS Symposium. AAAS Press, Washington, DC, p 36-39

Levin SA (1999) Fragile dominion: complexity and the com mons. Perseus Books, Reading, MA

Lubchenco J (1994) The scientific basis of ecosystem management: framing the context, language, and goals. In: Zinn J, Corn ML (eds) ecosystem management: status and potential. 103rd Congress, 2nd Session, Committee Print. US Government Printing Office, Superintendent of Documents, Washington, DC, p 33-39

Ludwig D, Hilborn R, Walters C (1993) Uncertainty, resource exploitation, and conservation: lessons from history. Science 260:17-36

MacCall AD (1986) Changes in the biomass of the California Current system. In: Sherman K, Alexander LM (eds) Variability and management of large marine ecosystems. AAAS Selected Symposium 99. Westview Press, Inc, Boulder, CO, p 33-54

Mangel M (1991) Empirical and theoretical aspects of fisheries yield models for large marine ecosystems. In: Sherman K, Alexander LM, Gold BD (eds) Food chains, yields, models, and management of large marine ecosystems Westview Press, Inc, Boulder, CO, p 243-261

McGlade J (ed) (1999) Advanced ecological theory: principles and applications. Blackwell Science, Ltd. Oxford

Mee L (1992) The Black Sea in crisis: a need for concerted international action. Ambio 21(4):1278-1286

Mondjanagni AC, Adam KS, Langley P (1998a) Côte d'Ivoire - profil environnemental de la zone côtière. Centre pour l'environnement et le développement en Afrique (Ceda), Cotonou

Mondjanagni AC, Adam KS, Langley P (1998b) Profil de la zone côtière du Bénin. Centre pour l'environnement et le développement en Afrique (Ceda), Cotonou

Murawski SA (1996) Can we manage our multispecies fisheries? In: Sherman K, Jaworski NA, Smayda TJ (eds) The Northeast Shelf ecosystem: assessment, sustainability, and management. Blackwell Science, Cambridge, MA, p 491-510

NOAA (National Oceanic and Atmospheric Administration) (1993) Emerging theoretical basis for monitoring the changing states (health) of large marine ecosystems. summary report of two workshops: 23 April 1992, National Marine Fisheries Service, Narragansett, Rhode Island, and 
11-12 July 1992, Cornell University, Ithaca, New York. NOAA Technical Memorandum, NEFSC, Woods Hole, MA

NOAA (1998) Status of fishery resources off the northeastern United States for 1998. NOAA Technical Memorandum NMFS-NE-115. Northeast Fisheries Science Center, Woods Hole, MA

Norton BG, Ulanowicz RE (1992) Scale and biodiversity policy: a hierarchical approach. Ambio 21(3):244-249

NSTF (North Sea Task Force) (1991) Scientific activities in the framework of the North Sea Task Force. North Sea Environmental Report No. 4. North Sea Task Force, Oslo and Paris Commissions, International Council for the Exploration of the Sea, London

NSQSR (North Sea Quality Status Report) (1993) Oslo and Paris Commissions, London. Olsen and Olsen, Fredensborg

Ntiba MJ (1998) Trawl survey strategies and applications for assessing the changing state of fish communities in large marine ecosystems. In: Sherman $\mathrm{K}$, Okemwa EN, Ntiba MJ (eds) Large marine ecosystems of the Indian Ocean: assessment, sustainability, and management. Blackwell Science, Inc, Cambridge, MA, p 23-43

O'Connor TP, Ehler CN (1991) Results from the NOAA National Status and Trends Program on distribution and effects of chemical contamination in the coastal and estuarine United States. Environ Monit Assess 17:33-49

Overholtz WJ, Nicolas JR (1979) Apparent feeding by the fin whale Balaenoptera physalus, and humpback whale, Megoptera novaeanglae, on the American sand lance, Ammodytes americanus, in the Northwest Atlantic. Fish Bull US 77:285-287

Pauly D, Christensen V (1995) Primary production required to sustain global fisheries. Nature 374:255-257

Pauly D, Christensen V, Dalsgaard J, Froese F, Torres F Jr (1998) Fishing down marine food webs. Science 279: $860-863$

Payne PM, Wiley DN, Young SB, Pittmann S, Clapham PJ, Jossi JW (1990) Recent fiuctuations in the abundance of baleen whales in the southern Gulf of Maine in relation to changes in selected prey. Fish Bull US 88:687-696

PG-ENRO (Environment and Natural Resources Office of the Provincial Government of Batangas) (1996) Strategic environmental management plan for the Batangas Bay region. MPP-EAS Technical Report No. 3. GEF/UNDP/IMO Regional Programme for the Prevention and Management of Marine Pollution in the East Asian Seas, Quezon City, Philippines

Pimm SL (1984) The complexity and stability of ecosystems. Nature 307:321-326

Pope JG (1977) Collecting fisheries assessment data. In: Gulland JA (ed) Fish population dynamics. J Wiley \& Sons, New York, p 63-82

Rangeley R, Thiam B, Andreson A, Lyle C (1994) International river basin organizations in Sub-Saharan Africa. Technical Report No. 250. World Bank, Washington, DC

Rapport DJ (1992) What is clinical ecology? In: Costanza R, Norton BG. Haskell BD (eds) Ecosystem health: new goals for environmental management. Island Press, Washington, DC, p 223-228

Reid PC (1999) North Sea ecosystem: status report. In: Kumpf $H$, Steidinger $K$, Sherman K (eds) The Gulf of Mexico large marine ecosystem: assessment, sustainability, and management. Blackwell Science, Inc, Malden, MA, p 476-489

Rosenberg AA, Fogarty MJ, Sissenwine MP, Beddington JR, Shepherd JG (1993) Achieving sustainable use of renewable resources. Science 262:828-829
Sainsbury KJ (1988) The ecological basis of multispecies fisheries, and management of a demersal fishery in tropical Australia. In: Gulland JA (ed) Fish population dynamics, 2nd edn. J Wiley \& Sons, New York, p 349-382

Scully RT, Brown WY, Manheim BS (1986) The convention for the conservation of Antarctic marine living resources: a model for large marine ecosystem management. In: Sherman $\mathrm{K}$, Alexander LM (eds) Variability and management of large marine ecosystems. AAAS Selected Symposium 99. Westview Press, Inc, Boulder, CO, p 281-286

Sherman K (1994) Sustainability, biomass yields, and health of coastal ecosystems: an ecological perspective. Mar Ecol Prog Ser 112:277-301

Sherman K (1998) Large marine ecosystems: assessment and management from drainage basin to ocean. In: Proceedings of the Stockholm Water Symposium, August 10-15, 1997. With rivers to the sea: interaction of land activities, fresh water and enclosed coastal seas. Stockholm International Water Institute (SIWI), Stockholm, p 151-166

Sherman K, Tang Q (eds) (1999) Large marine ecosystems of the Pacific Rim: assessment, sustainability, and management. Blackwell Science. Inc, Malden, MA

Sherman K, Jaworski NA, Smayda TJ (eds) (1996) The northeast shelf ecosystem: assessment, sustainability, and management. Blackwell Science, Inc, Cambridge, MA

Sherman K, Okemwa EN, Ntiba MJ (eds) (1998) Large marine ecosystems of the Indian ocean: assessment, sustainability, and management. Blackwell Science, Inc, Malden, MA

Sissenwine MP (1986) Perturbation of a predator-controlled continental shelf ecosystem. In: Sherman K, Alexander LM (eds) Variability and management of large marine ecosystems. AAAS Selected Symposium 99. Westview Press, Inc, Boulder, CO, p 55-85

Sissenwine MP, Cohen EB (1991) Resource productivity and fisheries management of the northeast shelf ecosystem. In: Sherman K, Alexander LM, Gold BD (eds) Food chäins, yields, models, and management of large marine ecosystems. Westview Press, Inc, Boulder, CO, p 107-123

Smayda T (1991) Global epidemic of noxious phytoplankton blooms and food chain consequences in large ecosystems. In: Sherman K, Alexander LM, Gold BD (eds) Food chains, yields, models and management of large marine ecosystems. Westview Press, Inc, Boulder, CO, p 275-308

Solow AR (1994) Detecting change in the composition of a multispecies community. Biometrics 50:556-565

Solow AR, Sherman K (1997) Testing for stability in a predator-prey system. Ecology 78(8):2624-2627

Stockholm Water Symposium/EMECS (1998) Proceedings: with rivers to the sea: Interaction of land activities, fresh water and enclosed coastal seas. Stockholm International Water Institute (SIWI), Stockholm

Sutinen J and 15 coauthors (1998) A framework for monitoring and assessing socioeconomics and governance of large marine ecosystems. Final Report to NOAA on Contract No. 40NNF700378. University of Rhode Island and Northeast Fisheries Science Center, Kingston, RI

Svanberg O (1992) Toxic effects monitoring in Baltic Sea coastal areas. In: McKenzie DH, Hyatt DE, McDonald VJ (eds) Ecological indicators, Vol 1. Proceedings of the International Symposium on Ecological Indicators, October 16-19, 1990. Fort Lauderdale, Elsevier Science Publishers Ltd, Essex, p 413-423

Tang $Q$ (1989) Changes in the biomass of the Yellow Sea ecosystems. In: Sherman K, Alexander LM (eds) Biomass yields and geography of large marine ecosystems. AAAS Selected Symposium 111. Westview Press, Inc, Boulder, CO, p 7-35 
Tang Q (1993) Effects of long-term physical and biological perturbations on the contemporary biomass yields of the Yellow Sea ecosystem. In: Sherman K, Alexander LM, Gold BD (eds) Large marine ecosystems: stress, mitigation, and sustainability. AAAS Symposium. AAAS Press, Washington, DC, p 79-93

Taylor P, Groom AJR (eds) (1989) Global issues in the United Nations framework. MacMillan, London

Turgeon D, Bricker SB, O'Connor TP (1992) National status. and trends program: chemical and biological monitoring of US coastal waters. In: McKenzie DH, Hyat DE, McDonald VJ (eds) Ecological indicators, Vol 1. Elsevier Science Publishers Ltd, Essex, p 425-457

UNDP (United Nations Development Programme) (1999a) strategic action plan for the integrated management, sustainable development and protection of the Benguela Current large marine ecosystem. UNDP, Windhoek

UNDP (1999b) Benguela Current large marine ecosystem program: transboundary diagnostic analysis. UNDP, Windhoek

UNIDO/UNDP/NOAA/UNEP (1997) Gulf of Guinea large marine ecosystem project. Second Meeting of the Steering Committee, Cotonou (Bénin) 11-12 March 1997. Report GEF/GOG-LME/Sc-2 Gulf of Guinea Regional Coordination Centre, Abidjan

Varanasi U, Stein JE, Johnson LL, Collier TK, Casillas E, Myers MS (1992) Evaluation of bioindicators of contaminant exposure and effects in coastal ecosystems. In:

Editorial responsibility: Otto Kinne (Editor),

Oldendort/Luhe, Germany
McKenzie DH, Hyat DE, McDonald VJ (eds) Ecological indicators, Vol 1 Elsevier Science Publishers Ltd, Essex. p $461-498$

White $\mathrm{HH}$, Robertson A (1996) Biological responses to toxic contaminants in the Northeast Shelf large marine ecosystem. In: Sherman K, Jaworski N, Smayda $T$ (eds) The Northeast shelf ecosystem: assessment, sustainability and manacgement. Blackwell Science, Cambridge, MA, p 259-283

Williams $N$ (1998) Overfishing disrupts entire ecosystems. Science 279.809

Williams R (1993) Evaluation of new techniques for monitoring and assessing the health of large marine ecosystems. In: Rapport D (ed) NATO advanced research workshop evaluating and monitoring the health of large-scale ecosystems. Springer-Verlag, Berlin, p 257-272

Zhang CI, Kim S (1999) Living manne resources of the Yellow Sea ecosystem in Korean waters: status and perspectives. In: Sherman K, Tang Q (eds) Large marine ecosystems of the Pacific Rim: assessment, sustainability and manage ment. Blackwell Science, Inc, Malden, MA, p 163-178

Zinn J, Corn ML (eds) (1994) Ecosystem management; status and potential: summary of a workshop convened by the Congressional Research Service, March 24 and 25, 1994 Washington, DC. In: Ecosystem management: status and potential. 103rd Congress, 2nd Session, Committee Print US Government Printing Office, Superintendent of Documents, Washington, DC, p 1-14

Submitted: June 29, 1999; Accepted: September 28, 1999 Proofs received from author(s): November 18, 1999 